Shih-Ming Pi,

Ph.D., Professor, College of Business, Chung Yuan Christian University, Taiwan

ORCID ID: 0000-0001-9074-9303

email: sampi@cycu.edu.tw

Ghassan Al-Zu'bi,

Chung Yuan Christian University, Taiwan

ORCID ID: 0000-0001-7641-3707

email: ghassan.khaledalzubi@gmail.com

Correspondence author: ghassan.khaledalzubi@gmail.com

\title{
THE KNOWLEDGE MANAGEMENT AND SAFETY COMPLIANCE IN OECD ECONOMIES: SOME EXPERIENCE FOR JORDAN INDUSTRIAL SECTOR
}

Abstract. The paper investigates the role of knowledge management and safety compliance in OECD economies and applies some recommendations for the Jordan industrial sector. This study reveals the main problems with safety compliance which are resulted in fatal and non-fatal occupational injuries. The main purpose is to determine the innovation and economic factors that influence safety compliance to provide a relevant recommendation for improving the situation. The research object is chosen as countries because they present generalized information on safety compliance and provide an opportunity to develop some policy recommendations. In the frame of the paper investigation of the knowledge management and safety compliance was carried out in the following logical sequence: first, it provides the relevant literature review, then it discusses methodology and data description, and at last, it presents empirical results with policy recommendation and conclusions. There was collected a panel data for 29 OECD economies on such indicators as fatal and non-fatal occupational injuries per 100000 workers, wealth, energy efficiency indicators, gross fixed capital formation, patent applications, high-technology exports and manufacturing value-added. Methodological tools of the research were the random effect estimations in Stata for the latest available data 2010-2015. The obtained results showed that the increase in GDP per capita in selected OECD economies reduces the fatal occupational injuries per 100000 workers. Thus, an increase in GDP per capita by 1000 USD lead to decrease in fatal occupational injuries per 100000 workers by 0,039. Also, an increase in GDP per capita by 1000 USD leads to an increase in non-fatal occupational injuries per 100000 workers by 7,8. The other important innovation variables are high technological export and patent application by residents, which reduce the level of non-fatal occupational injuries. Systematization of literary sources and approaches for solving the problem of safety compliance indicates that both economic and innovation parameters have to be addressed to reduce the fatal and non-fatal occupational injuries. The results of this research can be useful for policy-makers who are responsible for knowledge management and safety compliance.

Keywords: knowledge management, safety compliance, OECD economies, innovations, occupational injuries.

Introduction. Safety compliance is an important factor in knowledge management which needs to be taken into account. According to statistics, in 2018, around 2.3 million people died at enterprises (around 5.8 persons per 100000 workers). In 2000, around 3.2 million people died for the same reason (around 7.2 persons per 100000 workers) (International Labour Organization, 2020). It is possible to observe the slight reduction in the figures for the total number of deaths and its quantity per 100000 workers. This reduction can be explained by many factors, including technological advancements, better safety conditions, and the protective equipment of higher quality. Nevertheless, the problem of providing safety in workplaces is still urgent. Safety compliance of higher-level allows solving various problems. Indeed, occupational safety, in particular, is extremely necessary, as it enables workers to return safely to their

Cite as: Pi, Sh.-M., \& Al-Zu'bi, Gh. (2020). The Knowledge Management and Safety Compliance in OECD Economies: Some Experience for Jordan Industrial Sector. Marketing and Management of Innovations, 4, 255-265. http://doi.org/10.21272/mmi.2020.4-21 
Sh.-M., Pi, Gh., Al-Zu'bi. The Knowledge Management and Safety Compliance in OECD Economies: Some Experience for Jordan Industrial Sector

family, friends, and communities (Nejad et al., 2017). Safe work environments allow workers to feel comfortable in their work environments, thus reducing absenteeism and increasing productivity. The involvement of employees in the life of the company is the significant advantage of safety compliance measures. Through encouraging workers to participate in various training sessions, team-building seminars, decision-making lectures, etc., it is possible to increase the level of multilateral collaboration and improve the perception of new initiatives (Mullen et al., 2017). Another great advantage is fewer expenditures for different purposes, including insurance, refunds for bad-quality products, treatment costs. High safety culture is a feature of an innovative enterprise with certain standards of quality, which can be good for company brand management. $28,8 \%$ of the GDP of Jordan are the revenues from the industrial sector. At the same time, around $20 \%$ of the population work in industrial enterprises. Mineral mining, construction, oxidizing agents, chemical production, coal processing, potash mining are the developed large-scale industries of Jordan, where the safety risks are naturally high (International Monetary Fund, 2020). The Jordanian society and economy have suffered human and financial losses as a result of the poor safety record in the industry. Therefore, it is essential to investigate the dynamics of the development of safety compliance.

Literature Review. The scientific review results demonstrate that many authors primarily described the theoretical aspects of safety compliance. Sharon Clarke (1999) emphasized the importance of safety compliance in the industrial sector as well as the necessity of its understanding by typical workers. The involvement of workers as a key factor of successful safety compliance was primarily mentioned by Diaz and Cabrera. The concept of knowledge management as an effective tool for safety compliance was developed in the late 20th century. Janz and Prasarnphanich (2003) stated that a knowledge-centred culture was necessary for providing a high level of safety compliance. Griffin and Neal (2000) researched the interaction between knowledge management and safety compliance. Podgorski (2010) described the difference between tacit and explicit knowledge for different safety management systems. Nonaka (1994) and Ringel-Bickelmaier and Ringel (2010) agreed that various knowledge management tools are essential for providing safety compliance measures such as personal training, team-building programs, decisionmaking seminars, etc. The actions mentioned above underline the necessity of knowledge management usage for industrial safety compliance. Cox and Cox (1991) were among the first scientists, who developed the concept of safety compliance. They stated that safety compliance was a variety of safety rules and standards, which have an impact on organizational safety and the process of becoming safe. Besides, Cox and Cox (1991) described the experience of European enterprises in providing a certain level of safety culture. The particular necessity of safety compliance management in hazardous industrial and nonindustrial spheres was described by Pidgeon and O'Leary (1994), Griffin and Hu (2013). These authors stated that the higher level of danger in the industry, the higher standards and approaches have to be applied to them. In the publications, Kelloway et al. (2017) and Kaynak et al. (2016) described the importance of specific management styles to provide safety compliance. There are many practical approaches for evaluation of safety compliance in the industry. For example, Amponsah-Tawiah and Mensah (2016) describe the experience of safety compliance in the mining sector in Ghana. Smibert and Fleming (2017) provided another interesting publication about the assessment of safety compliance. The authors described the successful transformation in the railway industry in the USA after setting up safety compliance. El-Mashaleh analyzed the problems in the construction industry in Jordan. The researchers stated that construction was the dangerous industry with high death rates even in the most developed countries. Therefore, safety compliance measures need to be well-prepared and properly applied. Despite there are some publications about safety compliance management in Jordan, there is still a lack of comprehensive researches concerning the level of safety compliance in Jordan.

The purpose of this research is to analyze the theoretical and empirical aspect of safety compliance in OECD economies, to evaluate the level of safety compliance in Jordan and provide recommendations 
Sh.-M., Pi, Gh., Al-Zu'bi. The Knowledge Management and Safety Compliance in OECD Economies: Some Experience for Jordan Industrial Sector

for government, non-governmental organizations, and employers for better management of safety compliance.

Methodology and research methods. The industrial safety compliance originated together with systemic management approach within industrialized economies in the early nineteen's century. The knowledge management is mainly the application of certain rules and practices which saves human lives during the industrial production and servicing. Therefore, it plays a vital role in industrial safety compliance. The main industrial safety compliance practices describe the proper reaction to dangerous situations.

For gaining the research purpose, it was collected a panel data for 29 OECD economies (Australia, Austria, Belgium, Czech Republic, Denmark, Estonia, Finland, France, Germany, Greece, Hungary, Ireland, Italy, Latvia, Lithuania, Luxembourg, Mexico, Netherlands, Norway, Poland, Portugal, Slovak Republic, Slovenia, Spain, Sweden, Switzerland, Turkey, United Kingdom, United States). It is expected that fatal occupational/professional injuries per one hundred thousands of workers and non-fatal occupational/professional injuries per one hundred thousands of workers are dependent on economic and innovation variables. The following formula could express the conceptual model (1).

$$
\text { Foi, nFoi }=f\left(G d p_{-} \text {per_capita,Gdp_energy,Gfc,Pa,Mva,Hte,Foi, nFoi }\right)
$$

where Foi - Fatal occupational/professional injuries per one hundred thousands of workers; nFoi Non-fatal occupational/ professional injuries per one hundred thousands of workers; Gdp_per_capita GDP per capita (constant 2010 US\$); Gdp_energy - GDP per unit of energy use (constant 2011 PPP \$ per $\mathrm{kg}$ of oil equivalent); Gfc - Gross fixed capital formation (\% of GDP); Pa - Patent applications, residents; Mva - Manufacturing, value added (\% of GDP); Hte - High-technology exports ( $\%$ of manufactured exports).

In turn, it is expected that the wealth indicators reduce fatal occupational/professional injuries per one hundred thousands of workers (e.g. the richer the economy the more safe occupational conditions are). The innovation variable of patent application by residents should reduce the occupational injuries. The same is expected with another innovation variable high-technology exports. The Stata application allowed providing empirical estimations.

Results. Many approaches in defining the concept of «safety compliance» exist. Most of them concern the wide variety of functions connected with providing safety and security in workplaces.

The involvement of employees is an essential component of the current development of relationships in the industry. Thus, the ways of employees involvement include different options for message exchanges within an organization or an enterprise (Paul, 2016). Workers particularly always possess a full-scale awareness of their work duties, specific rules and standards. Besides, they can suggest the various improvement of different options.

Three main specific priorities of workplace health are as follows: maintaining and supporting the performance and wellbeing productivity of the workforce, the enhancement of the working culture and develop towards the health and wellbeing of employment relationships and cultural groups and the development of them, which contributes to OHS at the workplace, thus also contributing to the improved community climate and proper functioning and enhance the quality of businesses (Smibert and Fleming, 2017). In this context, the concept of the company environment is meant to reflect the reward system of value that the undertaking relevant adopts. There are different ways to use safety compliance tools in the enterprise. According to the effectiveness of various measures, they could be presented in a pyramid. Herewith, the lowest stage is a less effective measure, and the highest stage is a more effective one (Fig.1). 
Sh.-M., Pi, Gh., Al-Zu'bi. The Knowledge Management and Safety Compliance in OECD Economies: Some Experience for Jordan Industrial Sector

Table 1. Definitions of the concept «safety compliance»

\begin{tabular}{ll}
\hline \multicolumn{1}{c}{ Source } & \multicolumn{1}{c}{ Definition } \\
\hline $\begin{array}{l}\text { International Labour } \\
\text { Organisation (2009) }\end{array}$ & $\begin{array}{l}\text { the study on preparation, identification, assessment, and management of risks that could } \\
\text { harm the safety and welfare of employees at work and requires considering the different } \\
\text { effects on the people of the community as a whole. } \\
\text { a collaborative area of medical coverage that allows a person to function in the most } \\
\text { dangerous ways for the wellbeing. }\end{array}$ \\
$\begin{array}{lll}\text { Paul (2016) } & \text { the beliefs, roles and values of workers concerning danger or protection. } \\
\text { the condition of compliance or the cycle of compliance with necessary security standards } \\
\text { and requirements. }\end{array}$ \\
$\begin{array}{ll}\text { Western et al., 2016 Pacific } \\
\text { WHO (2015) }\end{array}$ & $\begin{array}{l}\text { addressing all areas of occupational safety and health and relies primarily on key risk } \\
\text { management. }\end{array}$ \\
World Health & $\begin{array}{l}\text { a condition of full physical, emotional and social health, not only the absence of diseases } \\
\text { Organization (2016) diseases. }\end{array}$ \\
\hline
\end{tabular}

Sources: developed by the authors.

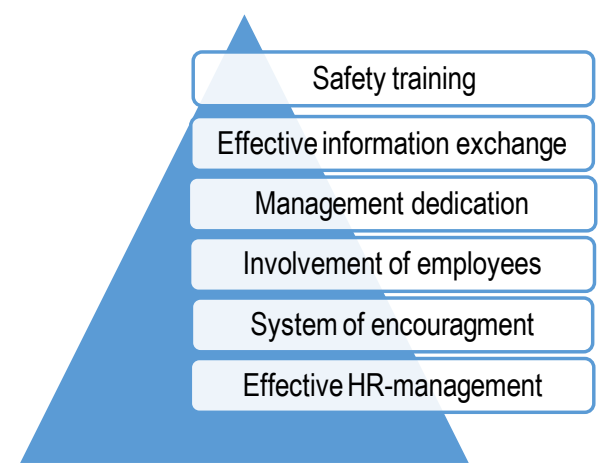

Figure 1. A pyramid of safety compliance measures

Source: developed by authors.

Training involves making employees know how to do things, advising workers about different ways to make their level of safety higher, or just offering workers knowledge (Amponsah-Tawiah and Mensah, 2016). Lifelong learning is also necessary for terms of compliance with health. Until this preparation, the company does not disperse the awareness produced by creativity and work experience. Training is an essential tool to inform employees and managers of the risks and controls at their workplaces. Therefore, they could work safer and more productive. But another function of education and learning is to enhance the understanding of safety compliance tools by employees and managers. Thus, these could contribute to their management and delivery. The safety compliance management would be encouraged by the introduction of individuals prepared to demonstrate a health-conscious approach in the jobs of employees. Some researches stated that safety compliance and its approaches via knowledge management were created in the sphere of human resources. Hiring processes are important for employing innovative employees with a certain level of preparedness for working in an organization or an enterprise with a high level of safety compliance. In the safety program, it is essential to integrate an encouraging part. Even not large-scale incentives, for example, $\$ 10$ monthly gift certificates for various services allow for on-site promotions or as redeeming facilities for the accumulation of spaces (Reason, 2016). For enhancing the safety message, overall security programs could be marked on several commercial gift cards. A suitably planned safety encouragement program strengthens the reporting of risk or announced action leading to trauma while providing payouts for less time-consuming accidents. 
Sh.-M., Pi, Gh., Al-Zu'bi. The Knowledge Management and Safety Compliance in OECD Economies: Some Experience for Jordan Industrial Sector

A dedication to protection, relating to the seen importance of managers and a dedication to physical health for employees, is the most significant feature of the atmosphere of health, provided that it is a wellknown predictor of protective habits of staff and accidents in a wide range of occupations. Management's dedication began at a high-ranking management level along with the Medical Center Administrator as the driving factors behind the effort to raise the number of accident events. This initiative would not have reached its degree of accomplishment without the sincere encouragement of different stages of the company's management. Clear and consistent communication is critical for compliance with safety. Continuous input from staff about health enforcement is often important as a number of significant accidents arise as a consequence of regular activity, which does not contribute to injury (Wang and Wu, 2019). Daily performance reviews may be given to workers by published reports and an enforcement summary Mei, et. al. (2020). Providing a decent level of safety compliance is an urgent priority for any enterprise in any country. Jordan is a country in Western Asia with the GDP (purchasing power parity) estimated at around 93 billion dollars. $28,8 \%$ of the GDP of Jordan are the revenues from the industrial sector. At the same time, approximately $20 \%$ of the population work in industrial enterprises. Jordan's export consists of minerals and chemical fertilizers $(7,1 \%)$, packaged and not packaged medicaments $(6,9 \%)$, natural calcium phosphates (6,6\%) (International Monetary Fund, 2020). The cooperation in export operations is set up with different countries, including the USA, Saudi Arabia, Kuwait, Iraq, and India. The internal market is also represented by gold mining, metal processing, etc. It means that Jordan has a developed heavy industry, where the level of safety compliance needs to be very high.

There are four key indicators to evaluate the effectiveness of safety compliance measures in Jordan: fatal occupational/professional injuries per one hundred thousands of workers (by countries), fatal occupational injuries per one hundred thousands workers (by years), non-fatal occupational/professional injuries per one hundred thousands of workers (by countries), non-fatal occupational/professional injuries per one hundred thousands of workers (by years) (International Labour Organization, 2020). According to Figure 2, the overall number of cases of fatal occupational/professional injuries per one hundred thousands of workers in Jordan is higher than in Germany, the United States of America and Ukraine. The number of such cases in Ukraine is 5.5 deaths per one hundred thousands workers, which is slightly lower than the global value -6.2 per one hundred thousands of workers. Jordan's number is twice higher than Ukraine's parameter and more than five times higher than the same indicator in Germany and the USA. This indicator witness about severe problems in preventing fatal industrial injuries in Jordan.

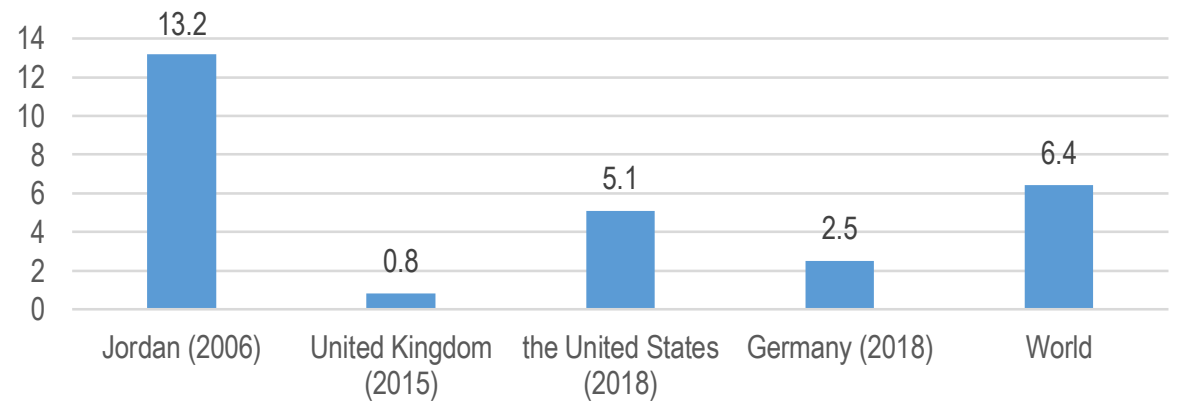

Figure 2. Fatal occupational/professional injuries per one hundred thousands of workers in selected economies

Source: developed by authors on the basis of International (Labor Organization, 2020).

Fatal occupational injuries per one hundred thousands workers (by years) demonstrate the tendency in changes of the fatal injuries (Figure 3). In Jordan, it is possible to observe an increase in the maximum 
Sh.-M., Pi, Gh., Al-Zu'bi. The Knowledge Management and Safety Compliance in OECD Economies: Some Experience for Jordan Industrial Sector

level in 2003 (15 cases) and a certain fall to 10 cases already in 2004. In turn, the general trend is stable. All figures are correlated between 9.2 and 15, which demonstrates the absence of significant steps to improve the situation with safety compliance in this country. Table 2 presents the empirical results for fatal occupational/professional injuries per one hundred thousands of workers.

Table 2. Regression results for fatal occupational/professional injuries per one hundred thousands of workers

\begin{tabular}{|c|c|c|c|c|c|c|}
\hline & & \multirow{2}{*}{\multicolumn{3}{|c|}{ Number of obs $=165$}} \\
\hline & & & & & & \\
\hline & & & & \multicolumn{3}{|c|}{ Number of groups $=29$} \\
\hline & & & & \multirow{2}{*}{\multicolumn{3}{|c|}{$\begin{array}{l}\text { Obs per group: } \\
\min =?\end{array}$}} \\
\hline & & & & & & \\
\hline & & & & \multicolumn{3}{|c|}{$\operatorname{avg}=5.7$} \\
\hline & & & & \multirow{2}{*}{\multicolumn{3}{|c|}{$\begin{array}{l}\max =6 \\
\operatorname{corr}(\mathrm{u} i \mathrm{i}, \mathrm{X})=0 \text { (assumed) }\end{array}$}} \\
\hline & & & & & & \\
\hline & & & & \multicolumn{3}{|c|}{$(-3)$} \\
\hline \multicolumn{2}{|c|}{$\begin{array}{l}\text { Random-effects GLS regression } \\
\text { Group variable: id } \\
\text { R-sq: } \\
\text { within }=0.0008 \\
\text { between }=0.3246 \\
\text { overall }=0.2878 \\
\text { Wald chi2 }(6)=13.27 \\
\text { Prob > chi2 }=0.0389 \\
\text { Foi } \quad \text { Coef. }\end{array}$} & Std. Err. & $\mathbf{Z}$ & $P>|z|$ & \multicolumn{2}{|c|}{$95 \%$ Conf. Interval } \\
\hline Gdp_per_capita & -.000039 & .0000147 & -2.67 & 0.008 & -.000068 & -.000010 \\
\hline Gdp_energy & .047311 & .0798845 & 0.59 & 0.554 & -.1092596 & .2038818 \\
\hline GfC & .072181 & .049341 & 1.46 & 0.143 & -.0245254 & .1688879 \\
\hline $\mathrm{Pa}$ & $9.87 \mathrm{e}-06$ & $6.00 \mathrm{e}-06$ & 1.64 & 0.100 & $-1.89 \mathrm{e}-06$ & .0000216 \\
\hline Hte & -.036650 & .039452 & -0.93 & 0.353 & -.1139747 & .0406743 \\
\hline Mva & -.02510 & .0500376 & -0.50 & 0.616 & -.1231798 & .0729638 \\
\hline cons & 3.01641 & 1.245717 & 2.42 & 0.015 & .5748578 & 5.457978 \\
\hline
\end{tabular}

Source: developed by authors on the basis of International (Labor Organization, 2020).

Table 2 shows that the increase in GDP per capita in selected OECD economies reduces the fatal occupational/professional injuries per one hundred thousands of workers. Thus, an increase in GDP per capita by 1000 USD lead to decrease in fatal occupational/professional injuries per one hundred thousands of workers by 0,039 . The other variables are statistically not significant.

Another important indicator for evaluating the level of safety compliance is non-fatal occupational/professional injuries per one hundred thousands of workers (by countries). According to Figure 3, the overall number of cases of non-fatal occupational/professional injuries per one hundred thousands of workers in Jordan is 2312,6 which is near to the average world figure - 2248,2. In Germany, the number of such cases is higher than in Jordan or around the world on average (Fig.3).

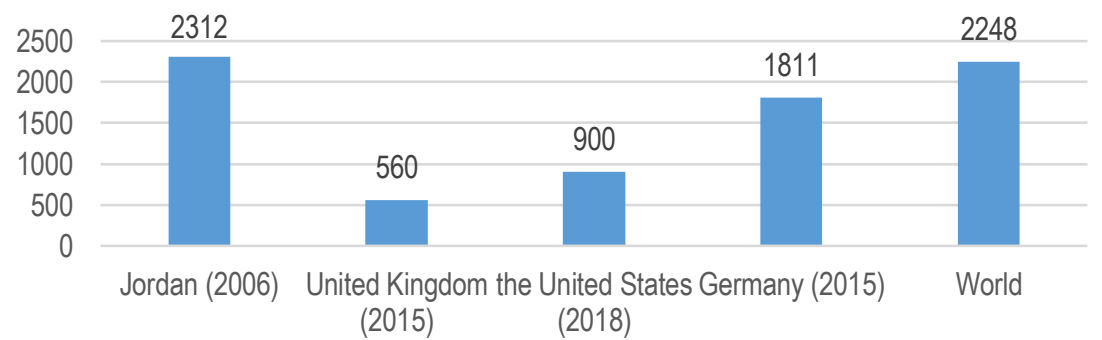

Figure 3. Non-fatal occupational/professional injuries per one hundred thousands of workers Source: developed by authors on the basis of International (Labor Organization, 2020).

Similar indicator (non-fatal occupational/professional injuries per one hundred thousands of workers (by years)) is important for analyzing the interaction between safety compliance measures and preventing 
industrial trauma of any scale. According to statistics, the positive tendency (the reduction in the number of such cases) is observed. In 2001 there were almost 3571 cases of non-fatal injury per one hundred thousands of employees, while in 2006 - approximately 2313. This indicator demonstrates that Jordan is developing its safety management in the context of safety compliance. It is essential to distinguish the difference between stable dynamic in cases of fatal occupational injuries per one hundred thousands of workers and a positive tendency in non-fatal ones. The second indicator is more reliable in the understanding of the obtained results. It is possible to observe a significant reduction in non-fatal injuries in the industry (from 3571 cases in 2001 to 2313 in 2006), whereas the number of fatal ones does not change significantly. It is expected that the wealth indicators reduce non-fatal occupational/professional injuries per one hundred thousands of workers, e.g. the richer the economy, the more safe occupational conditions are. The innovation variable of the patent application by residents should reduce occupational injuries. The same is expected with another innovation variable high-technology exports. The Stata application allowed conducting empirical estimations. Table 3 presents the empirical results for non-fatal occupational/professional injuries per one hundred thousands of workers.

Table 3. Regression results for non-fatal occupational/professional injuries per one hundred thousands of workers

\begin{tabular}{|c|c|c|c|c|c|c|}
\hline \multicolumn{5}{|c|}{ Random-effects GLS regression } & \multicolumn{2}{|c|}{ Number of obs $=165$} \\
\hline \multicolumn{5}{|c|}{ Group variable: id } & \multicolumn{2}{|c|}{ Number of groups $=29$} \\
\hline \multicolumn{5}{|l|}{ R-sq: } & \multicolumn{2}{|c|}{ Obs per group: } \\
\hline \multicolumn{5}{|l|}{ within $=0.0721$} & \multicolumn{2}{|c|}{$\min =2$} \\
\hline \multicolumn{5}{|l|}{ between $=0.0113$} & \multicolumn{2}{|c|}{$\operatorname{avg}=5.7$} \\
\hline \multicolumn{5}{|c|}{ overall $=0.0093$} & \multicolumn{2}{|l|}{$\max =6$} \\
\hline \multicolumn{5}{|c|}{$\begin{array}{l}\text { Wald chi2 } 2(6)=7.73 \\
\text { corr }\left(u \_i, X\right)=0 \text { (assumed) }\end{array}$} & \multicolumn{2}{|c|}{ Prob $>$ chi2 $=0.2586$} \\
\hline nFoi & Coef. & Std.Err. & $\mathbf{z}$ & $P>|z|$ & \multicolumn{2}{|c|}{$95 \%$ Conf. Interval } \\
\hline Gdp_per_capita & .01283 & .0078488 & 1.64 & 0.102 & -.00255 & .0282163 \\
\hline Gdp_energy & -39.694 & 30.13742 & -1.32 & 0.188 & -98.762 & 19.37369 \\
\hline GfC & 18.4036 & 16.73421 & 1.10 & 0.271 & -14.394 & 51.20209 \\
\hline $\mathrm{Pa}$ & -.00215 & .0030962 & -0.69 & 0.487 & -.00821 & .0039179 \\
\hline Hte & -23.383 & 15.03948 & -1.55 & 0.120 & -52.860 & 6.093214 \\
\hline Mva & -10.200 & 18.14174 & -0.56 & 0.574 & -45.757 & 25.35698 \\
\hline cons & 1452.144 & 446.2732 & 3.25 & 0.001 & 577.465 & 2326.824 \\
\hline
\end{tabular}

Source: developed by authors on the basis of International (Labor Organization, 2020).

Table 3 shows that the growth in GDP per capita in selected OECD economies increases the nonfatal occupational/professional injuries per one hundred thousands of workers. Thus, an increase in GDP per capita by 1000 USD lead to an increase in non-fatal occupational/professional injuries per one hundred thousands of workers by 7,8 . It stands to mention that it is not the increase in GDP per capita itself, but it could be related to the development level of the insurance system and financial system. Thus, more developed economies are more likely to register more cases of non-fatal occupational injuries officially. The other essential innovation variables are high technological export and patent application by residents, which reduce the level of non-fatal occupational/professional injuries per one hundred thousands of workers. In the case of Jordan, it is seen that the level of safety compliance in the industrial enterprises in Jordan is not sufficient. Many official reports have already asked the Jordan authorities to strengthen the control in this sphere. Though Jordan has already adopted the national legislative framework and has ratified many International Labour Organization conventions on safety compliance, the practical results are still not significant. Several studies figure out certain reasons to explain it. Not sufficient level of understanding the importance of setting up proper standards of organizational safety, providing out-of- 
Sh.-M., Pi, Gh., Al-Zu'bi. The Knowledge Management and Safety Compliance in OECD Economies: Some Experience for Jordan Industrial Sector

date statistical data and other information on key indicators of safety compliance, problems with appropriate safety training create significant barriers in proper safety compliance. Where specific problems with safety compliance have been identified, it is essential to improve the situation with the mutual work of governmental institutions, non-governmental organizations, and employers as follows. For the government:

- to intensify their relations with the International Labour Organization at the political and economic aspects;

- to provide and update statistical data on different indicators concerning labour relations (including the key ones);

- to increase the level of cooperation between proper governmental institutions and the business sector (especially, with the heavy-scale one, where the problem with safety compliance is very urgent);

- to develop the national legislative framework according to the international standards and the conditions of key documents in labour protection sphere;

- to provide a certain level of juridical responsibility for abuses in the safety compliance sphere;

- to promote the enterprises to use up-to-date equipment by financial and non-financial tools.

- For non-governmental organizations:

- to strengthen the control for safety compliance performance in the industrial sector of Jordan;

- to publish and share novel informational materials about the importance of organizational safety and the possible ways of its achievement;

- to cooperate with the government and business for providing help with setting specific standards in safety compliance management;

- to raise awareness among workers about their role in safety compliance processes and their whole impact on industrial safety.

For employers:

- to spend more money on safety compliance with the understanding of future fewer expenditures;

- to set up the mechanism of knowledge management influence on the development of safety compliance in an enterprise;

- to create and intensify the mechanism of involvement of workers in the safety compliance projects;

- to change the system of rewards to encourage workers, who concern safety compliance;

- to improve HR standards to employ workers interested in organizational safety and culture;

- to provide an effective communication mechanism within one enterprise or an organization.

Conclusions. Safety compliance of higher-level allows solving diverse problems. Through encouraging workers to participate in various training sessions for safety compliance, team-building programs, decision-making seminars, it is possible to increase the level of multilateral collaboration and improve the perception of new initiatives. The obtained results indicated the existence of many approaches to defining the concept of «safety compliance». Moreover, most of them concern the wide variety of functions connected with providing safety and security in workplaces. The pyramid of safety compliance measures consists of involvement of employees, safety training, hiring practices, the system of rewards management dedication feedback and communication.

The economic situation in Jordan was characterized as a background for the research. In turn, Jordan is a country in Western Asia, with the GDP (purchasing power parity) estimated approximately 93 billion dollars. Herewith, $28,8 \%$ of the GDP of Jordan are the revenues from the industrial sector. At the same time, about $20 \%$ of the population works in industrial enterprises. Jordan's export consists of minerals and chemical fertilizers $(7,1 \%)$, packaged and not packaged medicaments $(6,9 \%)$, natural calcium phosphates $(6,6 \%)$ It is essential to understand that a lot of employees in Jordan work in hazardous industries (mineral mining, construction, oxidizing agents, chemical production, coal processing, potash mining), where the 
Sh.-M., Pi, Gh., Al-Zu'bi. The Knowledge Management and Safety Compliance in OECD Economies: Some Experience for Jordan Industrial Sector

level of employees' safety needs to be high. There are four key indicators to evaluate the effectiveness of safety compliance measures in Jordan as follows: fatal occupational/professional injuries per one hundred thousands of workers (by countries), fatal occupational injuries per one hundred thousands workers (by years), non-fatal occupational/professional injuries per one hundred thousands of workers (by countries), non-fatal occupational/professional injuries per one hundred thousands of workers (by years).

According to statistics, the overall number of cases of fatal occupational/professional injuries per one hundred thousands of workers in Jordan is higher than in Germany, the United States of America and Ukraine. Jordan's number is twice higher than Ukraine's parameter and more than five times higher than the same indicator in Germany and the USA. This indicator witness about severe problems in preventing fatal industrial injuries in Jordan. In turn, non-fatal occupational/professional injuries per one hundred thousands of workers (by countries) is another important indicator to evaluate the level of safety compliance. Statistical data demonstrates that the overall number of cases of non-fatal occupational/professional injuries per one hundred thousands of workers in Jordan is 2312,6 , which is near to the average global value - 2248,2. Similar indicator (non-fatal occupational/professional injuries per one hundred thousands of workers (by years) is important for analyzing the interaction between safety compliance measures and preventing industrial trauma of any scale. The result of statistical data analysis indicated the positive tendency in the reduction of the number of such cases.

In turn, the paper provides the recommendations (for government, non-governmental organizations, and employees) for improving organizational safety, where the barriers for effective safety compliance exist. Thus, thegovernment needs to intensify the relations with the International Labour Organization at the political and economic aspects. Moreover it shold provide and update statistical data on different indicators concerning labour relations (including, the key ones) as well as develop the national legislative framework following the international standards and the conditions of key documents in labour protection sphere. Moreover, It is also necessary to provide a certain level of juridical responsibility for abuses in the safety compliance sphere and promote the enterprises to use up-to-date equipment by financial and nonfinancial tools.

In turn, non-governmental organizations have to strengthen the control for safety compliance performance in the industrial sector of Jordan. Furthermore, they need to publish and share novel informational materials about the importance of organizational safety and the possible ways of its achievement. It is also important to cooperate with government and business to provide help with setting certain standards in the safety compliance management and raise awareness among workers about their role in safety compliance processes and their whole impact on industrial safety.

Herewith, businesses should spend more money on safety compliance with the understanding of future fewer expenditures. Besides, they should set up the mechanism of knowledge management influence on the development of safety compliance in an enterprise and change the system of rewards to encourage workers, who take care of safety compliance. Businesses need to create and intensify the mechanism of involvement of workers in the safety compliance projects and improve HR standards to employ workers interested in organizational safety and culture and provide an effective communication mechanism within one enterprise or an organization.

Author Contributions: methodology, S. M. P. and G. A.; software, G. A.; validation, S. M. P.; formal analysis, S. M. P. and G. A.; investigation, G. A.; data curation, S. M. P. and G. A.; writing-original draft preparation, G. A.; writing-review and editing, S. M. P. and G. A.; visualization, G. A.; supervision, S. M. P. 
Sh.-M., Pi, Gh., Al-Zu'bi. The Knowledge Management and Safety Compliance in OECD Economies: Some Experience for Jordan Industrial Sector

\section{References}

Amponsah-Tawiah, K., \& Mensah, J. (2016). Occupational health and safety and organizational commitment: Evidence from the Ghanaian mining industry. Safety and health at work, 7(3), 225-230. [Google Scholar] [CrossRef]

Clarke, S. (2006). The relationship between safety climate and safety performance: a meta-analytic review. Journal of occupational health psychology, 11(4), 315. [Google Scholar] [CrossRef]

Cox, S., \& Cox, T. (1991). The structure of employee attitudes to safety: A European example. Work and stress, 5(2), 93-106. [Google Scholar] [CrossRef]

Griffin, M. A., \& Hu, X. (2013). How leaders differentially motivate safety compliance and safety participation: The role of monitoring, inspiring, and learning. Safety science, 60, 196-202. [Google Scholar] [CrossRef]

Griffin, M. A., \& Neal, A. (2000). Perceptions of safety at work: a framework for linking safety climate to safety performance, knowledge, and motivation. Journal of occupational health psychology, 5(3), 347. [Google Scholar] [CrossRef]

International Labour Organization. (2009). ILO Standards on Occupational Safety and Health: Promoting a safe and healthy

working environment. International Labour Conference, 98th Session. Retrieved from [Link]

International Labour Organization. (2020). ILOSTAT database. Retrieved from [Link]

International Monetary Fund. (2020). IMF database [database]. Retrieved from [Link]

Janz, B. D., \& Prasarnphanich, P. (2003). Understanding the antecedents of effective knowledge management: The importance of a knowledge-centered culture. Decision sciences, 34(2), 351-384. [Google Scholar] [CrossRef]

Kaynak, R., Toklu, A. T., Elci, M., \& Toklu, I. T. (2016). Effects of occupational health and safety practices on organizational commitment, work alienation, and job performance: Using the PLS-SEM approach. International Journal of Business and Management, 11(5), 146-166. [Google Scholar] [CrossRef]

Kelloway, E. K., Nielsen, K., \& Dimoff, J. K. (Eds.). (2017). Leading to occupational health and safety: How leadership behaviours impact organizational safety and well-being. John Wiley and Sons. [Google Scholar]

Mei, Q., Wang, Q., Liu, S., Zhou, Q., \& Zhang, J. (2020). Effects of organizational safety on employees' proactivity safety behaviors and occupational health and safety management systems in Chinese high-risk small-scale enterprises. International Journal of Occupational Safety and Ergonomics, 26(1), 101-111. [Google Scholar] [CrossRef]

Mullen, J., Kelloway, E. K., \& Teed, M. (2017). Employer safety obligations, transformational leadership and their interactive effects on employee safety performance. Safety science, 91, 405-412. [Google Scholar] [CrossRef]

Nejad, A. D., Gholamnia, R., \& Alibabaee, A. (2017). A new framework to model and analyze organizational aspect of safety control structure. International Journal of System Assurance Engineering and Management, 8(2), 1008-1025. [Google Scholar] [CrossRef]

Nonaka, I. (1994). A dynamic theory of organizational knowledge creation. Organization science, 5(1), 14-37. [Google Scholar] [CrossRef]

Paul, J. (2016). Organizational Safety Strategies: Which Management Practices are Most Effective in Reducing Employee Injury Rates. Business Journal for Entrepreneurs, 2016(3). [Google Scholar]

Petitta, L., Probst, T. M., \& Barbaranelli, C. (2017). Safety culture, moral disengagement, and accident underreporting. Journal of Business Ethics, 141(3), 489-504. [Google Scholar] [CrossRef

Pidgeon, N., \& O'Leary, M. (1994). Organizational safety culture: Implications for aviation practice. Aviation psychology in practice, 21-43. [Google Scholar]

Pilbeam, C., Doherty, N., Davidson, R., \& Denyer, D. (2016). Safety leadership practices for organizational safety compliance: Developing a research agenda from a review of the literature. Safety science, 86, 110-121. [Google Scholar] [CrossRef]

Podgorski, D. (2010). The use of tacit knowledge in occupational safety and health management systems. International Journal of Occupational Safety and Ergonomics, 16(3), 283-310. [Google Scholar] [CrossRef]

Reason, J. (2016). Managing the risks of organizational accidents. Routledge. [Google Scholar]

Ringel-Bickelmaier, C., \& Ringel, M. (2010). Knowledge management in international organisations. Journal of Knowledge Management. 14(4), 524-539 [Google Scholar] [CrossRef]

Smibert, D., \& Fleming, M. (2017). Is It Me or Is It You? Assessing the Influence of Individual and Organizational Factors on Safety Performance in the North American Railway Industry. In Advances in Human Aspects of Transportation (pp. 45-55). Springer, Cham. [Google Scholar] [CrossRef]

Tucker, S., Ogunfowora, B., \& Ehr, D. (2016). Safety in the c-suite: How chief executive officers influence organizational safety climate and employee injuries. Journal of applied psychology, 101(9), 1228. [Google Scholar] [CrossRef]

Wang, B., \& Wu, C. (2019). The evolution of organizational safety culture: A theoretical study. Chemical Engineering Transactions, 77, 301-306. [Google Scholar] [CrossRef]

World Health Organization. (2016). Definitions of health. International Medical Conference. Retrieved from [Link]

WPRO. (2015). Occupation of health. International Health Conference. Retrieved from [Link] 
Sh.-M., Pi, Gh., Al-Zu'bi. The Knowledge Management and Safety Compliance in OECD Economies: Some Experience for Jordan Industrial Sector

Ших-Мін Пі, Ph.D., профессор, Християнський університет Чун Юань, Тайвань

Гассан Аль-Зу'бі, Християнський університет Чун Юань, Тайвань

Управління знаннями та дотримання вимог технічної безпеки в країнах ОЕСР: досвід промислового сектору Йорданії

У статті авторами систематизовано основні проблеми при дотриманні норм техніки безпеки, що спричиняють смертельні та несмертельні випадки виробничого травматизму. Метою статті є формування низки рекомендацій щодо скорочення кількості випадків виробничого травматизму на основі аналізу інноваційних та економічних фракторів, які впливають на дотримання норм техніки безпеки. Об'єктом дослідження є 29 країн ОЕСР. Для досягнення поставленої мети, дослідження здійснено в наступній логічній послідовності: проаналізовано науковий доробок з досліджуваної тематики; обгрунтовано методологічний інструментарій та описано вихідні дані дослідження; представлено результати емпіричних розрахунків; сформовано відповідні висновки та рекомендації. Емпіричний аналіз базується на даних досліджуваних країн ОЕСР з 2010 по 2015 рік, а саме: показник смертельних та несмертельних виробничих травм на 100000 працівників; рівень достатку; показник енергоефективності; валовий приріст основного капіталу; запити на видачу патентів; експорт високотехнологічної продукиії; додана вартість в переробній промисловості. Практичну реалізацію дослідження здійснено з використанням методу оцінювання випадкових ефектів за допомогою програмного забезпечення Stata. На основі емпіричних результатів встановлено, що в окремих країнах ОЕСР, зростання ВВП на душу населення на 1000 дол. США сприяло зниженню рівня смертності від виробничого травматизму на 100000 працівників на 0,039. При цьому підвищення ВВП на душу населення на 1000 дол. США спричинило зростання показника несмертельних виробничих травм на 100000 працівників на 7,8. Окрім иього, у ході дослідження встановлено, що високотехнологічний експорт та кількість запитів на патенти сприяють зниженню рівня несмертельного травматизму. Результати аналізу наукового доробку та підходів до розв'язання проблеми дотримання техніки безпеки свідчать про те, що для зниження кількості смертельних та несмертельних випадків виробничого травматизму, необхідно враховувати інноваційні та економічні параметри. Отримані результати дослідження мають практичне значення для політичних діячів, відповідальних за управління знаннями та дотримання вимог техніки безпеки.

Ключові слова: управління знаннями, дотримання норм технічної безпеки, країни ОЕСР, інновації, виробничий травматизм

Manuscript received: 13.07.2020

(C) The author(s) 2020. This article is published with open access at Sumy State University 